\section{Enzymatic Penetration Through Intact Sulcular Epithelium}

by

\author{
Raul G. Caffesse, D.D.s., M.S., ${ }^{*}$ \\ Carlos E. Nasjleti, D.D.s. $\dagger$
}

BACTERIA PLAY a major role in the etiology of the inflammatory gingival periodontal lesions. ${ }^{9}$ However, the mechanisms involved in the production of the disease are not clear. Enzymes, endotoxins, immune reactions, cytotoxic metabolic products are among the probable active mechanisms. ${ }^{20}$ Direct invasion of the tissue by the bacteria has not been found except in acute necrotizing ulcerative gingivitis. ${ }^{8}$

It has been claimed that transport through sulcular epithelium (sulcular epithelium refers to "The epithelial lining of the gingival sulcus consisting of two parts: the oral sulcular epithelium and the junctional epithelium" ${ }^{25}$ ) takes place in both directions, although the inward route has a limited capacity when compared to that in the opposite direction. ${ }^{22}$ However, it has been shown that a topically applied foreign protein (horseradish peroxidase) can penetrate the nonkeratinized junctional epithelium of the rat, and reach the connective tissue. ${ }^{10}$ Similarly, tritium labeled albumin has been shown to penetrate the sulcular epithelium of the guinea pig. ${ }^{21}$

Schwartz et al. ${ }^{18}$ showed the penetration of tritiated endotoxins obtained from $E$. coli through intact sulcular epithelium in dogs. This result contrasted with a previous report by $\mathrm{Rizzo}^{13}$ demonstrating that endotoxins from Salmonella enteriditis and Fusobacterium polymorphum did not diffuse through an intact sulcular epithelium in rabbits. Some of the reasons for this apparent contradiction might be differences in molecular weight among the endotoxins tested, differences in species used, and that the systems used to test for penetration were different.

The effect of bacterial enzymes upon the gingival tissues also has been considered as a probable mechanism in the initiation of gingival inflammation. Hyaluronidase has received the most attention since the first report by Schultz-Haudt et al. ${ }^{16}$ in 1953 indicating widening of the intercellular spaces of the epithelium, dilated vessels, and vacuolation of the connective tissue after application of the enzyme. Smith and Ramfjord ${ }^{19}$ demonstrated a significantly higher inflammatory index at the base of the gingival sulcus following a long term application of

\footnotetext{
* The University of Michigan School of Dentistry, Department of Periodontics, Ann Arbor, Mich. 48104 and the Veterans Administration Hospital, Ann Arbor, Mich. 48105.

+ Veterans Administration Hospital, Ann Arbor, Mich. 48105.
}

hyaluronidase, with no significant variation at the apical level of the junctional epithelium. However, no difference could be found in gingival sulcus depth, length of junctional epithelium or loss of connective tissue support. Murphy and Stallard ${ }^{11}$ demonstrated the potential of this enzyme to penetrate a gingival sulcus with the help of a $2 \%$ solution of trypan blue dye. Hyaluronidase can be produced by constituents of the dental plaque ${ }^{12,15,17}$ and it can degrade hyaluronic acid which constitutes a principal component of the intercellular cementing substance of the epithelium, and of the connective tissue ground substance.

Also produced in the dental plaque is the enzyme collagenase which is capable of hydrolyzing native collagen. Bacteroides melaninogenicus may be mainly responsible for its production. ${ }^{5}$ However, both hyaluronidase and collagenase may originate from within the tissues ${ }^{1-7,23}$ and to our knowledge no study has shown the capacity for penetration of these enzymes in gingival tissues.

The purpose of the present study was to investigate possible penetration of tritium-labeled hyaluronidase and collagenase through intact sulcular epithelium of the marmoset by means of standard histologic and radioautographic techniques.

\section{Material AND Methods}

Five white lip marmosets (Saguinus negricollis) with complete dentitions, average weight $500 \mathrm{gm}$, imported from Colombia, were used in this study. All teeth were thoroughly scaled and polished 1 week prior to the experimental day in order to remove plaque and calculus and to minimize gingival inflammation.

Bovine testicular hyaluronidase type I, with approximate activity of $300 \mathrm{NF}$ units $/ \mathrm{mg}$, and collagenase from Clostridium hystolyticum fraction "A", type 1, with approximate activity of 200 units/mg, were obtained from Sigma Chemicals Co., St. Louis, Mo. These enzymes were custom tritiated by the tritium $\left(\mathrm{H}^{3}\right)$ gas exposure method of Wilzbach ${ }^{24}$ and subsequently purified, by Amersham/Searle Co., Arlington Heights, Ill. Immediately prior to the experiment, two aliquots of 10.3 $\mathrm{mg}$ of powdered tritiated hyaluronidase and one aliquot of $6.5 \mathrm{mg}$ of powdered tritiated collagenase were dissolved each in $5 \mathrm{ml}$ of bacteriostatic sodium chloride U.S.P., and stirred for 1 hour at room temperature. The concentration of the tritiated hyaluronidase was 2.06 $\mathrm{mg} / \mathrm{ml}$ (radioactivity 5.9 millicuries $/ \mathrm{ml}$ ), and that of the tritiated collagenase was $1.3 \mathrm{mg} / \mathrm{ml}$ (radioactivity 4.8 millicuries $/ \mathrm{ml}$ ). Of the two labeled hyaluronidase aliquots, one was heat inactivated. ${ }^{14}$ In addition, a pure nonlabeled sample of hyaluronidase was dissolved as previously indicated and was available for the experiment. The $\mathrm{pH}$ of these enzyme solutions was 5.5.

For the experiment, each marmoset was injected with 1 $\mathrm{mg}$ of Sernylan (phencyclidine hydrochloride). $\ddagger$ The

\footnotetext{
$\ddagger$ Bio-ceutic Laboratories, Inc., St. Joseph, Michigan.
} 
mouth was held open, the teeth isolated and the head positioned in such a way that the experimental area was kept free from saliva. No gingival inflammation could be observed at that time, which also was corroborated histologically from the control quadrants.

The experimental solutions were applied to the crown of the teeth by a Pasteur disposable pipette and allowed to flow into the sulcular area both buccally and lingually. Eight drops were administered over a 4-minute period (1 drop every 30 seconds). After waiting for 5 minutes, eight more drops were applied over 4 minutes. These sequences of applications were chosen after a pilot study with tritiated hyaluronidase and tritiated collagenase applied to Sprague-Dawley rats with times of 1,5 and 15 minutes.

Incisors, bicuspids and molars were included as experimental quadrants of each marmoset. One quadrant from each marmoset served as control. The remaining three quadrants for each monkey (total of 15 quadrants) received random application of one of the following solutions:

a) tritiated hyaluronidase

b) tritiated collagenase

c) unlabeled hyaluronidase followed by tritiated collagenase

d) inactivated tritiated hyaluronidase or

e) normal saline

Care was taken to avoid cross-over of the different

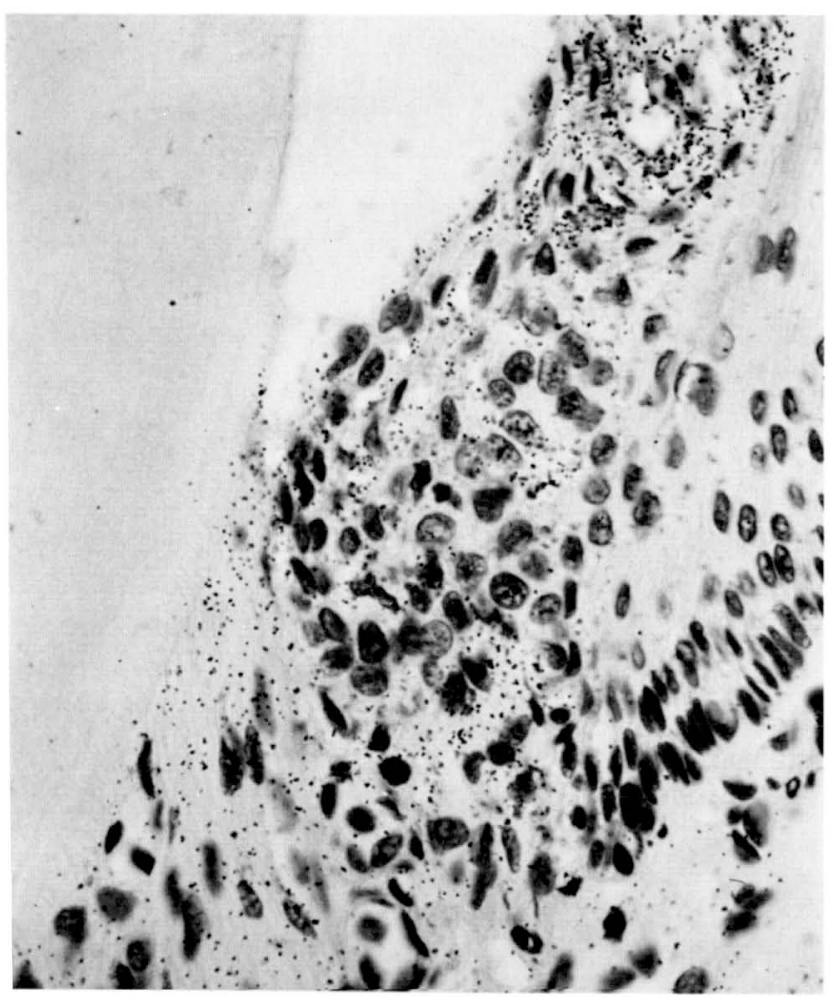

FigURE 1. Rat specimen. Junctional epithelium area, after application of tritiated hyaluronidase. Labeling spread through the bottom of the junctional epithelium into the connective tissue. Keratin acting as a barrier for penetration. $(H \& E$. Original magnification $\times 125$.)

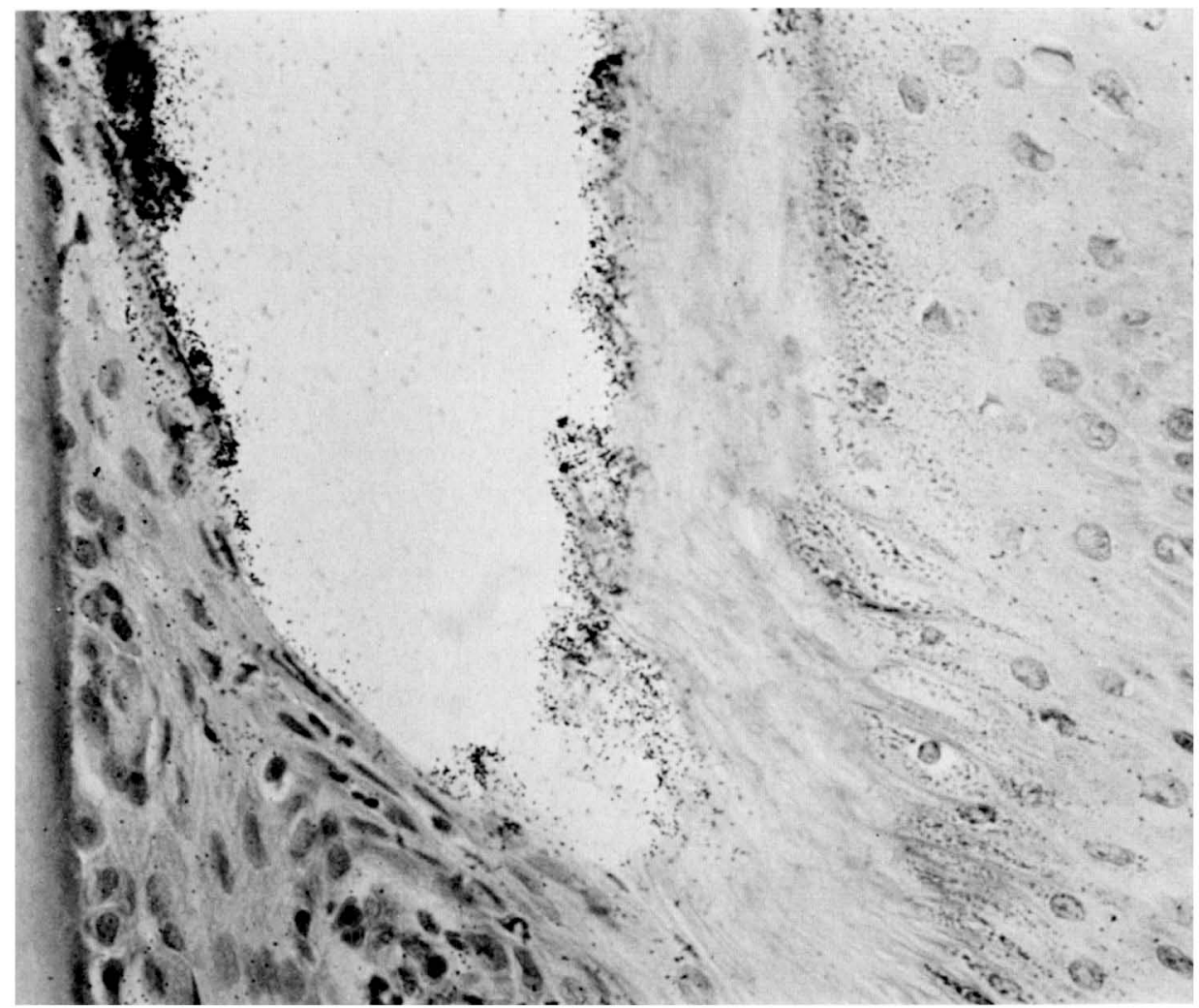

FIGURE 2. Rat specimen. Labeled collagenase has penetrated only superficially into the tissues at the bottom of the junctional epithelium. $(H \&$ E. Original magnification $\times 125$.) 
solutions at the midline. One minute after completion of the application the gingival area was washed with normal saline to remove remaining enzymes. Immediately thereafter, the marmosets were sacrificed.

After dissection the jaws were placed in $10 \%$ formalin for fixation, decalcified in $20 \%$ ethylenediamine tetraacetic acid adjusted to a $\mathrm{pH}$ of 7.4 with $\mathrm{NaOH}$, embedded in paraffin, sectioned every 6 to $7 \mu$ serially, mounted and processed for radioautography and for histologic evaluation. Radiographs were obtained applying Kodak's nuclear track emulsion (type NTB-3) and exposing the slides for 2 weeks. Afterwards they were developed in Kodak's D19 solution for 5 minutes, fixed and washed for half an hour, mounted in Permount and stained with Ehrlich's hematoxylin. Histologic slides also were stained with hematoxylin and eosin and Mallory connective tissue stains.

Radioautographs and histologic sections were evaluated on a blind basis.

\section{RESULTS}

The pilot study performed in rats showed that gingival keratinization acted as a definite barrier to penetration of both enzymes. However, tritiated hyaluronidase penetrated at the bottom of the gingival sulcus through the junctional epithelium. Labeling was observed between the epithelial cells and in the intercellular substance of the underlying connective tissue (Fig. 1). When tritiated collagenase was applied using the same time exposure, the penetration of the labeled enzyme at the bottom of

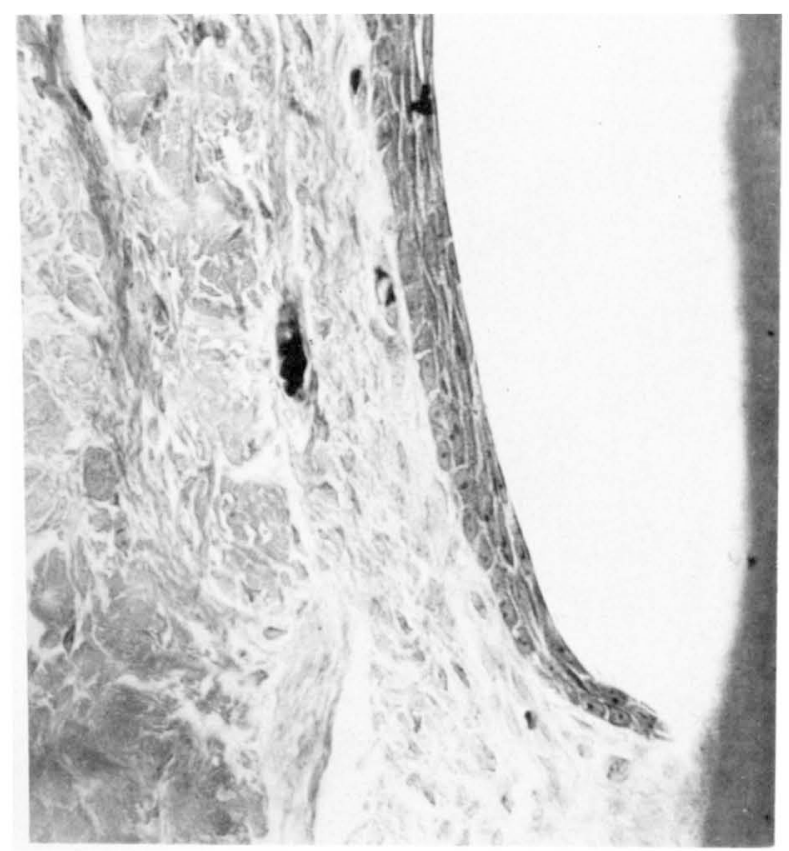

FIGURE 3. Marmoset specimen. Gingival sulcus of a control area. The bottom of the junctional epithelium is at the cemento-enamel junction. The underlying dense connective tissues show only a few scattered inflammatory cells. ( $H \& E$. Original magnification $\times 125$.) the sulcus and through the junctional epithelium, was minimal and superficial (Fig. 2).

The findings in the experimental marmosets were:

Control Specimens. The cervical third of the gingival sulcus is covered by a keratinized squamous epithelium, as an extension of the oral epithelium. The apical two-thirds are covered by a nonkeratinized squamous epithelium. The junctional epithelium is located at the cemento-enamel junction. Very few scattered inflammatory cells are seen underneath the sulcular epithelium (Fig. 3).

$H^{3}$ Hyaluronidase. Radioautographs show very extensive labeling extending throughout the nonkeratinized sulcular epithelium and into the underlying connective tissue (Fig. 4). The spread of labeled material is more pronounced through the oral sulcular epithelium than at the bottom of the junctional epithelium. Histologic sections (Fig. 5) show widening of the intercellular spaces of the epithelium and separation of the connective tissue elements with formation of vacuoles.

Inactivated $\mathrm{H}^{3}$ Hyaluronidase. Radioautographs show very minimal labeling within the tissues. There is accumulation of radioactive material in the gingival sulcus (Fig. 6). Histologic sections show minor changes involving only the superficial layers of the oral sulcular epithelium manifested as spongiosis and widening of intercellular spaces (Fig. 7).

$H^{3}$ Collagenase. Radioautographs show shallow and

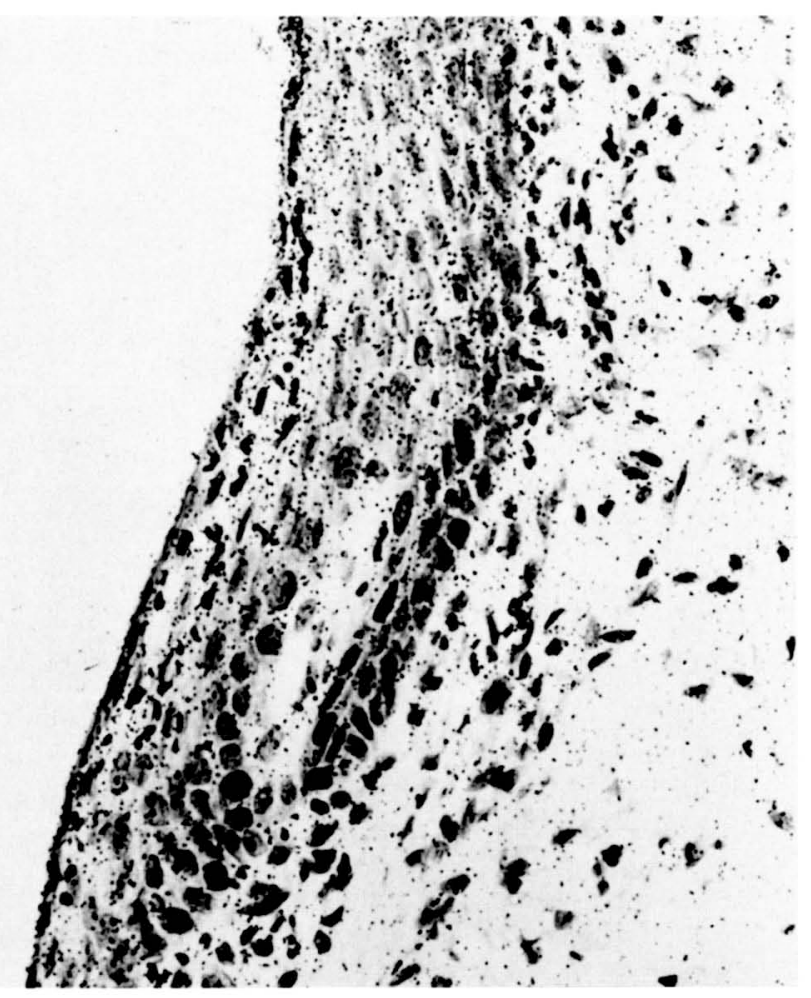

FIGURE 4. Marmoset specimen. Sulcular tissues after application of tritiated hyaluronidase. Labeling spread laterally to the oral sulcular epithelium deeply into the connective tissue. ( $H \&$ E. Original magnification $\times 125$.) 


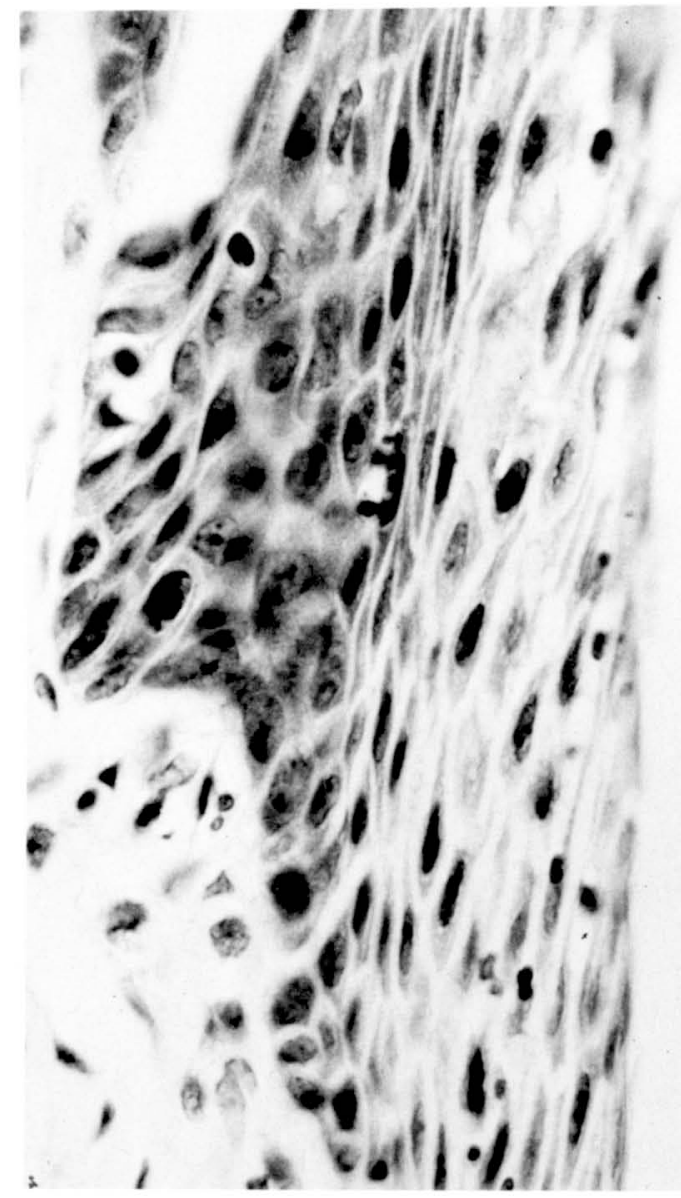

FIGURE 5. Marmoset specimen. Gingival sulcus after application of tritiated hyaluronidase. Widening of intercellular spaces. $(H \&$ E. Original magnification $\times 250$. $)$ minimal penetration of the labeled material into the sulcular epithelum and involving mainly the superficial layers of the oral sulcular epithelium (Fig. 8).

Histologic sections fail to show any significant changes in either the epithelium or the connective tissue (Fig. 9).

Unlabeled Hyaluronidase plus $\mathrm{H}^{3}$ Collagenase. When both enzymes are applied together (in this sequence), radioautographs show labeling, indicating collagenase spreading deeply into the connective tissue both laterally to the sulcular epithelium and apically to the junctional epithelium (Fig. 10). It is even possible to follow the spread of the labeling as a wedge deep between the connective tissue fibers (Fig. 11).

Histologic sections show edema in the connective tissue with disruption and separation of the collagen bundles.

Saline Application. No change can be seen in these specimens to differentiate them from those of the control areas.

\section{Discussion}

Hyaluronidase applied to the gingival sulcus seems to act as a "spreading factor" opening the intercellular spaces and altering the ground substance as it reaches the connective tissue. The radioautographs also indicate penetration of the hyaluronidase.

Collagenase apparently could penetrate deeply only when the entry had been prepared by hyaluronidase. Under such circumstances the enzyme will spread following the direction of the collagen fibers which might be disorganized and lysed. Otherwise, if hyaluronidase does

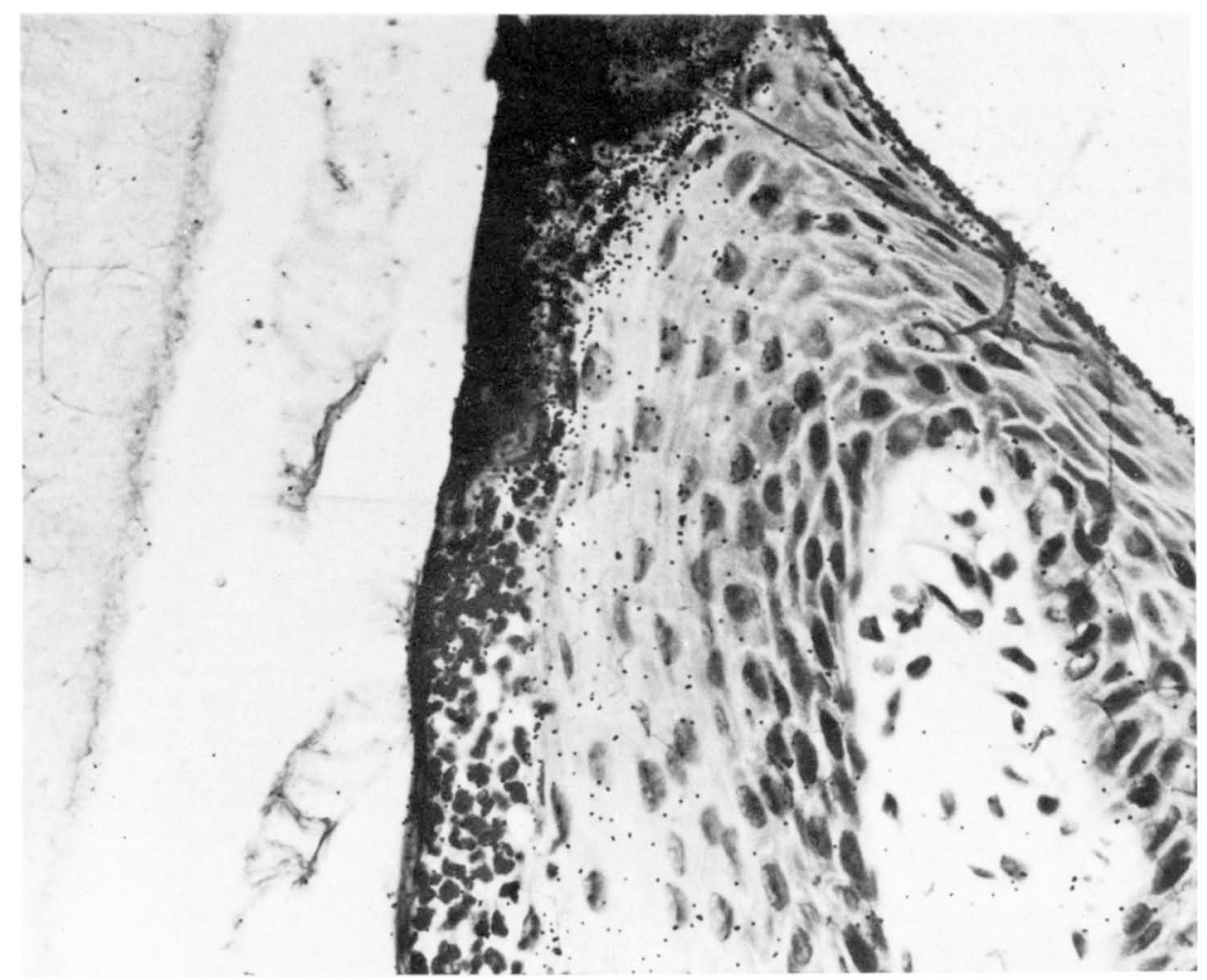

FIGURE 6. Marmoset specimen. Inactive hyaluronidase. Heavy accumulation of labeled material in the sulcus but minimal penetration within the tissue. $(H \& E$. Original magnification $\times 250$.) 


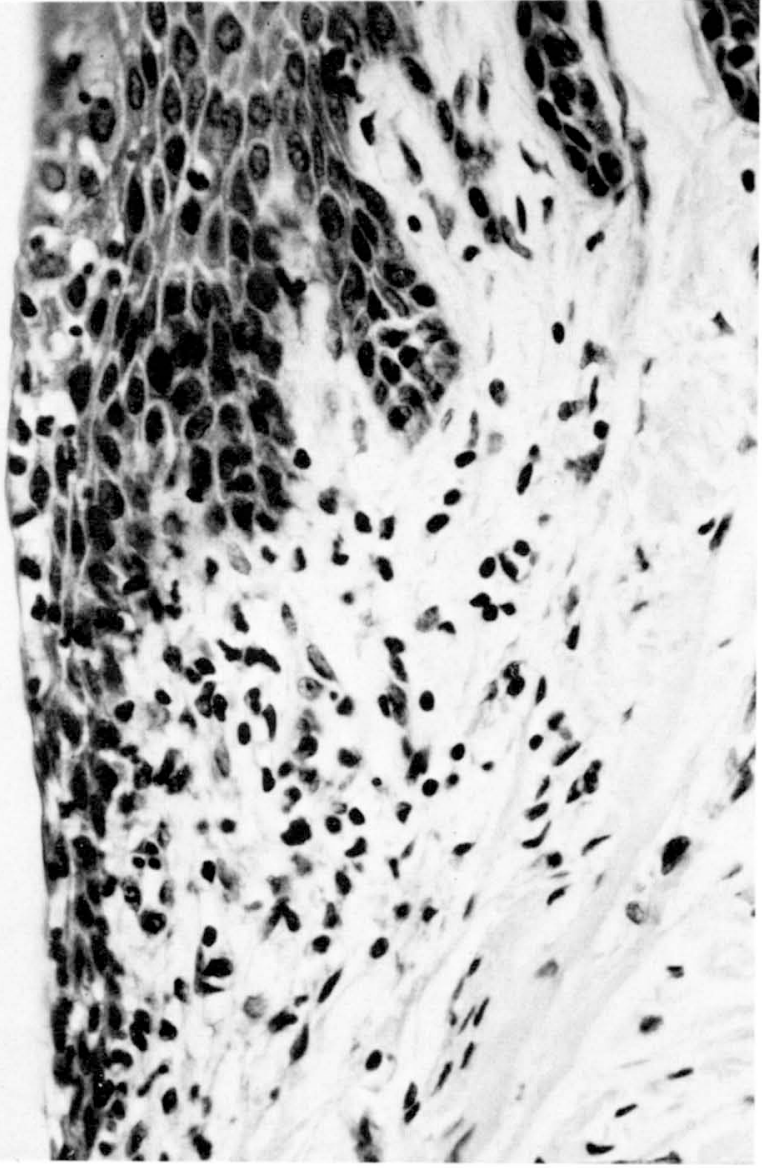

Figure 7. Marmoset specimen. Inactive hyaluronidase. Minimal changes in the superficial layer of the oral sulcular epithelium with widening of the intercellular spaces and spongiosis. $(H \& E$. Original magnification $\times 125$.)

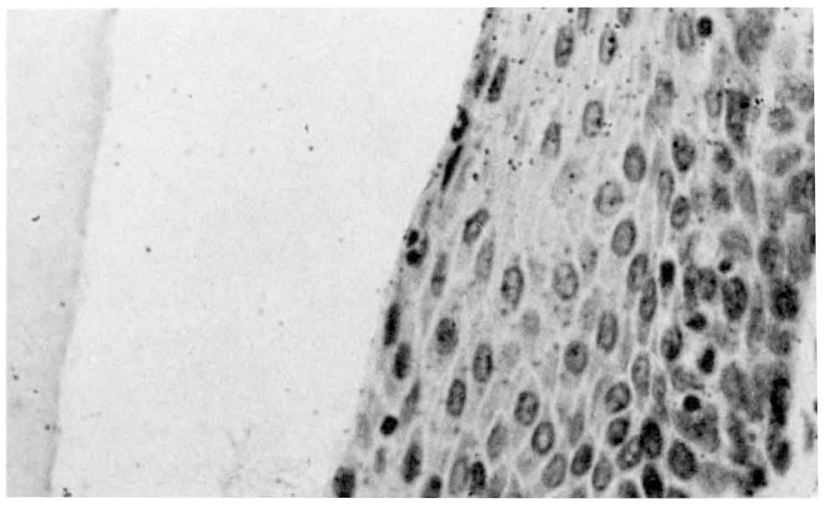

Figure 8. Marmoset specimen. Sulcular tissues. $H^{3}$ collagenase application. Minimal labeling within the tissue indicates the superficial penetration of the enzyme. ( $H \& E$. Original magnification $\times 125$.)

not prepare the way for the collagenase penetration, the spread will be very shallow limited to the surface layers of the epithelial tissues.

However, a definite drawback of the employed technique should be considered. The highly soluble enzymes used in this study resulted in considerable contamination of labeled material. The tissue manipulation and solvents used in routine radioautography unquestionably will induce some unpredictable spread of labeling.

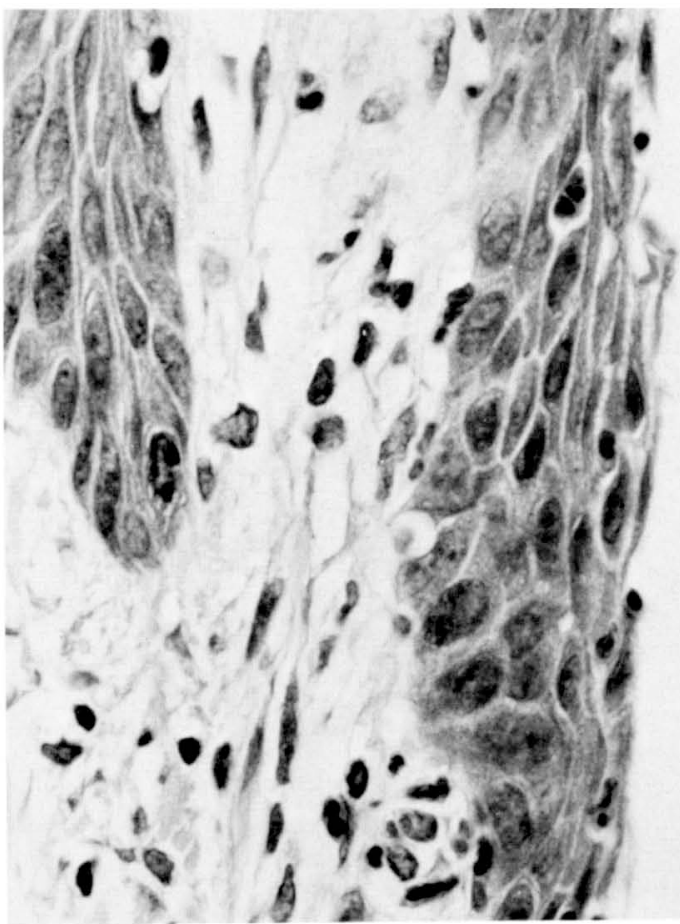

FIGURE 9. Marmoset specimen. Sulcular tissues after $H^{3}$ collagenase application. No significant change is seen either in epithelium or connective tissue. ( $H \& E$. Original magnification $\times 250$.)

Nevertheless, it was possible to determine gross penetration or lack of penetration of the enzymes. It also was possible to follow the pathways in those cases where penetration occurred.

It should be understood that the labeling was used only as a tracing material for enzymatic penetration, rather than indicating metabolic bond to cellular structures. In other words, the enzymes in this study were located extracellularly in the epithelial or connective tissues.

It is not known for sure whether bacterial enzymes are essential or if they even have some function in gingival inflammation since proof of their role in the pathogenesis of the disease is still lacking. ${ }^{20}$ It has been demonstrated clearly that hyaluronidase affecting the gingival structures can be of both bacterial and tissue origin. ${ }^{6,7,23}$ Nevertheless, bacterial hyaluronidase may be most important at the initial steps of the gingival lesion. The same may not be true for collagenase. Even if constituents of the dental plaque have the ability to produce collagenase, it appears that most of the enzyme affecting the connective tissue may be produced by the gingival tissues themselves. ${ }^{1-4}$

In this report the potential for penetration of these enzymes has been demonstrated. The pathways of spread and their possible sequences have been followed. In the nonkeratinized sulcular epithelium, enzymes seem to spread laterally more than apically. This agrees with histological findings in early gingivitis; the inflammatory process is mainly localized underneath the oral sulcular epithelium.

The lack of deep labeling in the areas treated with 


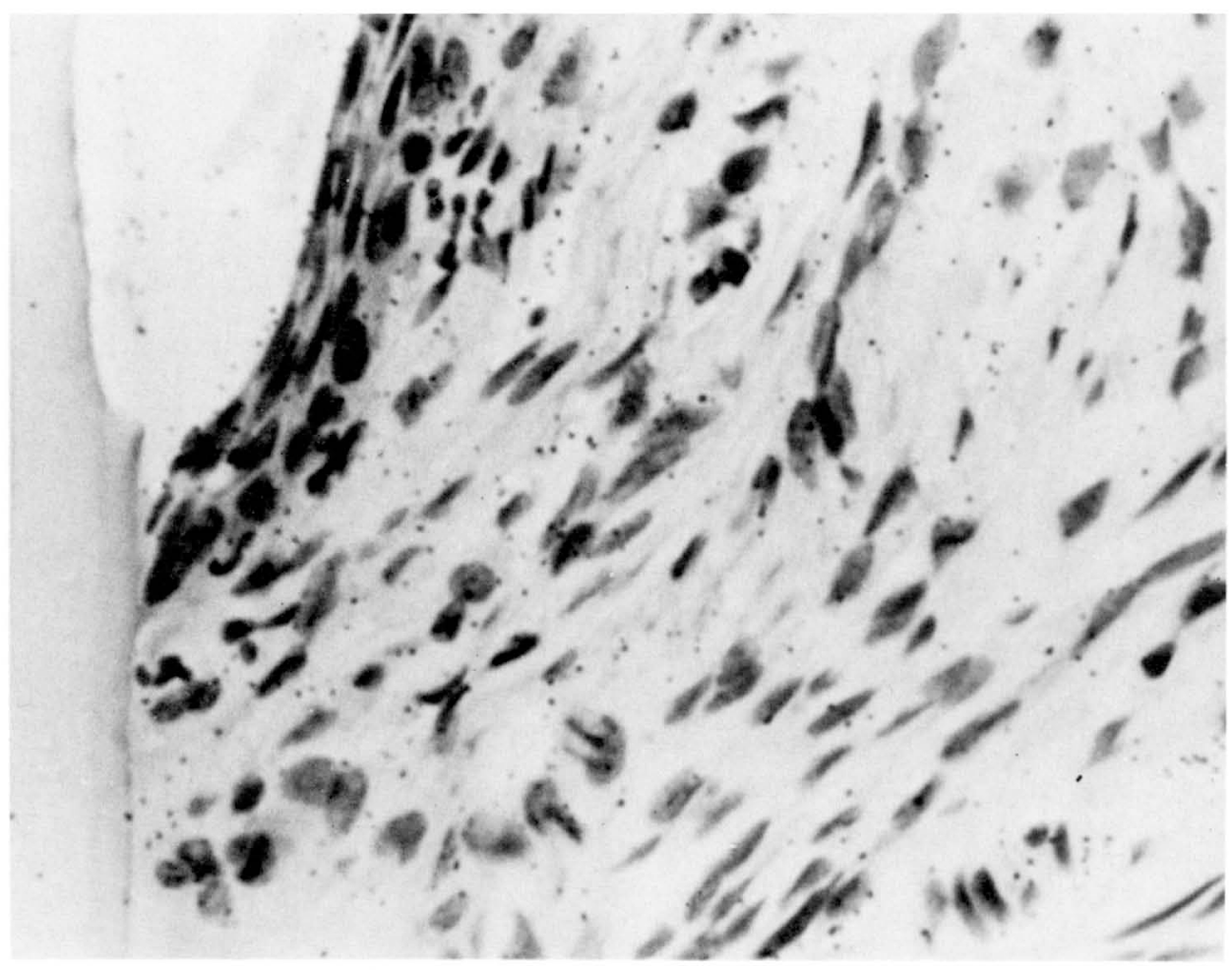

FIGURE 10. Marmoset specimen. Tissues after the application of unlabeled hyaluronidase followed by tritiated collagenase. Labeling (from collagenase) is seen deep in the tissues both laterally to the oral sulcular epithelium and apically to the junctional epithelium. (H \& E. Original magnification $\times 125$.)

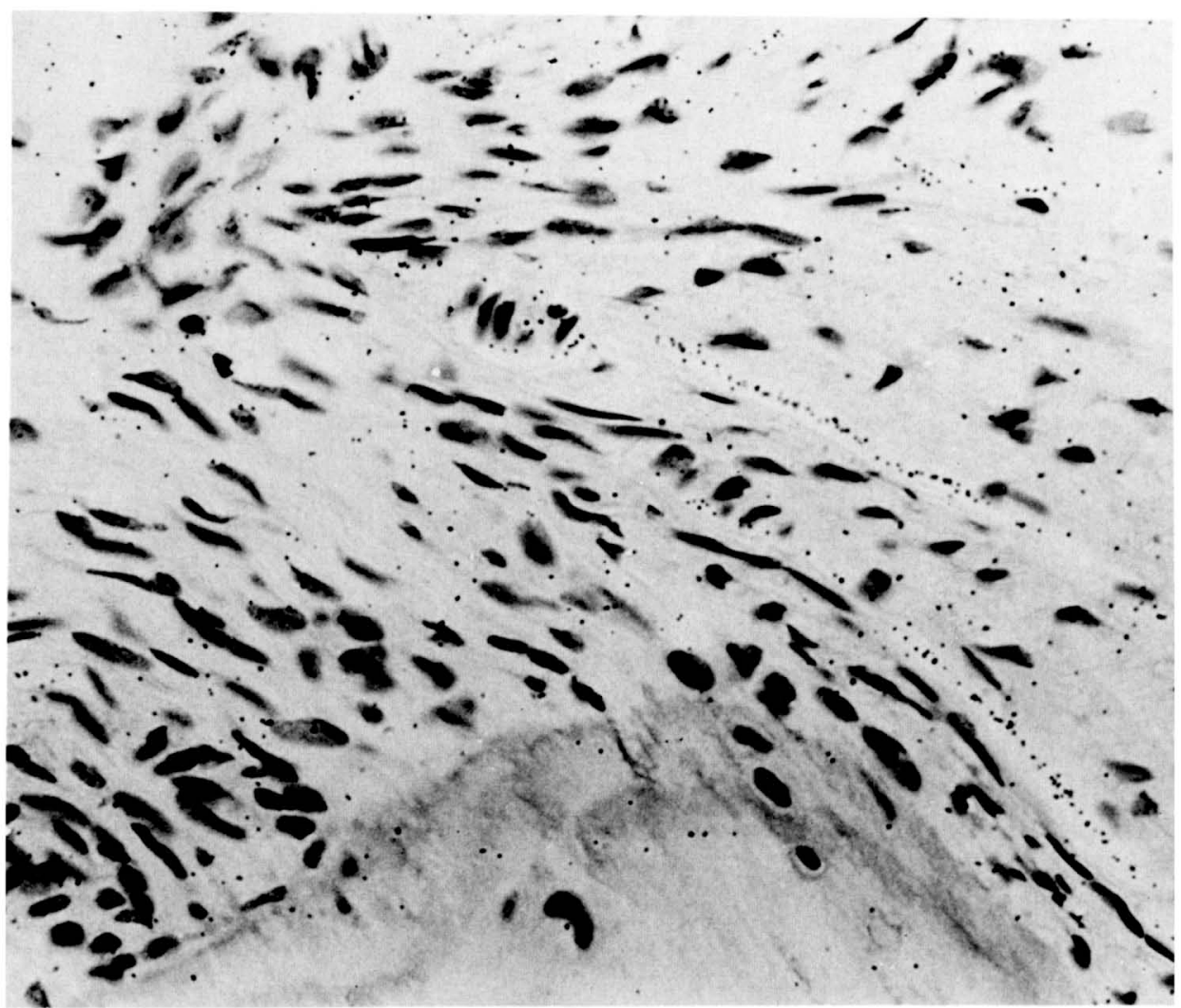

FIGURE 11. Marmoset specimen. Higher magnification of the lower right corner of Figure 10. Supracrestal tissues after the application of unlabeled hyaluronidase followed by tritiated collagenase. Labeling is seen deeply in the connective tissues wedging between connective tissue fibers. $(H \& E$. Original magnification $\times 250$.) 
inactivated tritiated hyaluronidase is an indication that the enzyme did not penetrate into the tissues.

However, a few aspects as for example, the degree of inactivation needed to prevent the penetration of the enzyme into the tissues, and the influence of $\mathrm{pH}$ variations on the degree of penetration require further study. The role of hyaluronidase seems to be very significant in the pathogenesis of periodontal disease since it may prepare the tissues for the action of other enzymes. It may be that hyaluronidase can be inactivated in the sulcus, thus preventing its effect upon the gingival tissues.

\section{Summary AND CONClusions}

To explore possible enzymatic penetration through intact sulcular epithelium, tritium labeled hyaluronidase and collagenase were applied to the gingival sulcus of five white lip marmosets. One quadrant per monkey remained untreated. Each remaining quadrant was randomly assigned to one of the following modalities of application: (a) tritiated hyaluronidase, (b) tritiated collagenase, (c) unlabeled hyaluronidase followed by tritiated collagenase, (d) inactivated tritiated hyaluronidase, or (e) normal saline as experimental controls. The enzymes were applied by means of a Pasteur disposable pipette. Eight drops were administered over a 4-minute period, one every 30 seconds. After a 5-minute waiting period a second series of eight applications was given over a 4-minute period. Radioautographic and standard histologic materials were obtained. Results suggest that:

1. Hyaluronidase has the ability to penetrate through intact nonkeratinized sulcular epithelium, widening the intercellular epithelial spaces and disorganizing the connective tissue ground substance.

2. Collagenase per se does not have the ability to penetrate through the intact sulcular epithelium. Its effect remains confined only to the superficial layers of the epithelium.

3. However, when collagenase application is preceded by hyaluronidase, collagenase spreads easily through the epithelium and deeply into the connective tissue. Hyaluronidase acts unquestionably as a spreading factor.

\section{ACKNOWLEDGMENTS}

The authors wish to acknowledge Miss Bobbie J. Haywood Research Chemist, who performed the enzyme inactivation tests and Mrs. Jean I. Simons for histological and radioautographic preparations; both from the staff of the Veterans Administration Hospital, Ann Arbor, Michigan.

\section{REFERENCES}

1. Bennick, A., and Hunt, A.: Collagenolytic activity in oral tissues. Arch Oral Biol 12: 1, 1967.
2. Beutner, E., Triftshouser, C., and Hazen, S.: Collagenase activity of gingival tissues from patients with periodontal disease. Proc Soc Exp Biol Med 121: 1082, 1966.

3. Fullmer, H.: Collagen and periodontal disease. A review. J Dent Res 50: 288, 1971.

4. Fullmer, H., and Gibson, W.: Collagenolytic activity in gingiva of man. Nature 209: 728, 1966.

5. Gibbons, R., and MacDonald, J.: Degradation of collagenous substrates by bacteroides melaninogenicus. $J$ Bacteriol 81:614, 1961 .

6. Goggins, J., Fullmer, H., and Steffek, A.: Hyaluronidase activity of human gingiva. Arch Pathol 85: 272, 1968.

7. Hopps, R., and Prout, R.: Identification of tissue and bacterial hyaluronidase in human saliva. $J$ Periodont Res 7: $236,1972$.

8. Listgarten, M.: Electronmicroscopic observations of the bacterial flora of acute necrotizing ulcerative gingivitis. $J$ Periodontol 36: 328, 1965.

9. Löe, H., Theilade, E., and Jensen, S.: Experimental gingivitis in man. J Periodontol 36: 177, 1965.

10. McDougall, W.: Penetration pathways of a topically applied foreign protein into rat gingiva. J Periodont Res 6: 89, 1971.

11. Murphy, P., and Stallard, R.: An altered gingival attachment epithelium: A result of the enzyme hyaluronidase. Periodontics 6: 105, 1968.

12. Nord, C., Frostell, G., and Söder, P.: Hyaluronidase production by oral microorganisms. Sven Tandlak Tidskr 62: $801,1969$.

13. Rizzo, A.: Adsorption of bacterial endotoxin into rabbit gingival pocket tissue. Periodontics 6: 65, 1968.

14. Rogers, H. J.: Hyaluronidases. Long, C. (ed), Biochemists Handbook, pp 242, Princeton, Van Nostrand Co., 1961.

15. Rosan, B., and Williams, N.: Hyaluronidase production by oral enterococci. Arch Oral Biol 9: 291, 1964.

16. Schultz-Haudt, S., Dewar, M., and Bibby, B.: Effects of hyaluronidase on human gingival epithelium. Science 117: 653, 1953.

17. Schultz-Haudt, S., and Scherp, H.: Production of hyaluronidase and beta-glucuronidase by viridans streptococci isolated from gingival crevices. $J$ Dent Res 34: 924, 1955.

18. Schwartz, J., Stinson, F., and Parker, R.: The passage of tritiated bacterial endotoxin across intact gingival crevicular epithelium. J Periodontol 43: 270, 1972.

19. Smith, F., and Ramfjord, S.: Hyaluronidase applied to the gingiva of Rhesus monkeys. J Periodontol 44: 361, 1973.

20. Socransky, S.: Relationship of bacteria to the etiology of periodontal disease. J Dent Res 49: 203, 1970.

21. Tolo, K.: A study of permeability of gingival pocket epithelium to albumin in guinea pigs and Norwegian pigs. $\mathrm{Arch}$ Oral Biol 16: 881, 1971.

22. Tolo, K.: Transport across stratified nonkeratinized epithelium. J Periodont Res 6: 237, 1971.

23. Tynelius-Bratthall, G.: Hyaluronidase activity in gingival crevicular material and in peritoneal exudate leukocytes in dog. J Periodont Res 7: 3, 1972.

24. Wilzbach, K.: Tritium labeling by exposure of organic compounds to tritium gas. J Am Chem Soc 79: 1013, 1957.

25. Schroeder, H., and Listgarten, N.: Fine structure of the developing epithelial attachment of human teeth. Monographs in Developmental Biology, Vol. 2, p 12. Basel, S. Karger, 1971. 